\title{
Anaerobic removal of 1-methoxy-2-propanol under ambient \\ temperature in an EGSB reactor
}

\author{
C. Lafita, J. M. Penya-roja, and C. Gabaldón*
}

Research Group GI AM, Department of Chemical Engineering, University of Valencia, Avda. Universitat s/n, 46100 Burjassot, Spain

*Corresponding author: Tel. +34 9635434 37, Fax: +34 9635448 98, E-mail address: carmen.gabaldon@uv.es

\section{Abstract}

Two laboratory scale expanded granular sludge bed (EGSB) reactors were operated at $18{ }^{\circ} \mathrm{C}$ and $25^{\circ} \mathrm{C}$, respectively, for the treatment of synthetic wastewater composed of ethanol and 1-methoxy-2-propanol (M2P) in a mass ratio of 4:1. Reactors were operated first with continuous wastewater supply and after with discontinuous substrate supply (5 days a week, 16 hours a day) to simulate shift working conditions. Under continuous wastewater supply chemical oxygen demand (COD), removal efficiency higher than 95\% was achieved at the end of the trial applying organic loading rates (OLR) of 29 and $43 \mathrm{~kg} \mathrm{COD} \mathrm{m}{ }^{-3} \mathrm{~d}^{-1}$ at $18{ }^{\circ} \mathrm{C}$ and $25^{\circ} \mathrm{C}$; thus corresponding to M2P OLR of 6.4 and 9.3 kg COD m${ }^{-3} \mathrm{~d}^{-1}$, respectively. During intermittent supply of substrate, good performance was recorded at both temperatures with an OLR of $30 \mathrm{~kg} \mathrm{COD} \mathrm{m}{ }^{-3} \mathrm{~d}^{-1}$ (M2P OLR of $6.6 \mathrm{~kg} \mathrm{COD} \mathrm{m}^{-3} \mathrm{~d}^{-1}$ ). After 56 hours without substrate supply a decline in methane yield of $15-30 \%$ was observed due to the deactivation of the biomass. Specific methanogenic activity (SMA) assays were carried out at the end of the experiments. SMA values using 1-methoxy-2-propanol as substrate were 24.3 and $7.8 \mathrm{ml} \mathrm{CH}_{4} \mathrm{gVSS}^{-1}$ 
$\mathrm{d}^{-1}$ at $25^{\circ} \mathrm{C}$ and at $18{ }^{\circ} \mathrm{C}$, respectively. This is the first attempt to investigate the removal of 1-methoxy-2-propanol by EGSB reactors.

\section{Keywords}

1-methoxy-2-propanol, EGSB, packaging wastewater, ambient temperature

\section{Introduction}

Glycol ethers are frequently use as a solvent due to their amphiphile behaviour. Because of their non-toxic properties propylene glycol ethers as 1-methoxy-2-propanol (M2P) are increasingly in use [1]. M2P is a highly soluble secondary alcohol produced by the reaction of 1,2-epoxy propane and methanol in the presence of a catalyst, and this is followed by distillation; European production is approximately 188 ktonnes. This compound is used in a wide variety of industrial applications as a solvent in water-based paints, varnishes and inks, in synthetic resin and rubber adhesives, and automobile and oven cleaners. According to the report from European Chemicals Bureau [2], in the packaging sector, it is used as a solvent of printing inks mixed with ethanol, with a yearly usage of this compound in the European Union of 12 ktons. Aerobic degradation of M2P has been well documented but anaerobic degradation was only reported from biodegradability tests by Goodwin in 1998 [2]. This author described an M2P removal of $38 \%$ of dissolved organic carbon (DOC) in 81 days of operation by using inoculum of municipal digester.

The process of anaerobic degradation under ambient and sub ambient temperatures $(<18$ ${ }^{\circ} \mathrm{C}$ ) is considered feasible for the treatment of a range of wastewaters, including for the treatment of wastewater with organic solvents [3-5]. Anaerobic treatment offers several advantages over other treatment options, such as lower operation costs, lower footprint and the production of methane, which can be used as a renewable energy source for 
industrial or domestic use [6]. In addition, as highlighted by the study of del Pozo et al. [7], low temperature anaerobic treatment is an attractive option for industrial wastewaters, particularly in temperate climates, compared to mesophilic operation. But low temperature causes a decrease of the maximum substrate utilisation rates and the maximum specific growth rates of microorganisms. Thus, temperature has a more significant effect on archaeal and bacteria communities than the presence of low biodegradable compounds [8]. Temperature changes particularly affects specialised acetogenic and methanogenic microorganisms, resulting in an increase of volatile fatty acids (VFA) that could result in an inhibition of the methanogenesis process [9]. However, the net biomass yield of methanogenic and acetogenic population increases with decreasing operational temperature [10]. As reported by Kashyap et al. [11] and Kettunen and Rintala [12], anaerobic digestion under psychrophilic temperatures is carried out by psychrotolerant mesophilic bacteria, so better performance is achieved when anaerobic biomass used for start-up of the reactor is previously acclimatised to psychrophilic temperatures.

Anaerobic high rate reactors based on granular sludge technology have become an interesting option for cost-effective and sustainable treatment of industrial wastewaters. Nowadays, major constructors sell more internal circulation $\left(\mathrm{IC}^{\circledR}\right)$ and expanded granular sludge bed (EGSB) reactors than conventional up-flow anaerobic sludge blanket (UASB) [6]. The high wastewater-biofilm contact via expanding the sludge bed makes EGSB a suitable technology to treat less biodegradable or toxic components found in wastewater [13], and enable high organic loads to be applied [14]. In addition, EGSB reactors provides enhanced accessibility to the anaerobic granular sludge between substrate and immobilised anaerobic biomass in higher viscosity water caused 
by low temperatures due to operation with high up flow velocity ( $\mathrm{v}_{\mathrm{up}}$ ), up to $10 \mathrm{~m} \mathrm{~h}^{-1}$. Otherwise, one of the most important disadvantages is that variations in flow or concentration may adversely affect the efficiency of anaerobic reactors [15]. However, studies carried out by Coelho et al. [16] demonstrated that mesophilic UASB reactors operated with intermittent substrate supply treating dairy wastewater could improve biological conversion and enhance methane production in comparison with UASB reactors operated with continuous substrate supply.

The present research is the first study on M2P anaerobic degradation in EGSB reactors and aims to evaluate the feasibility of anaerobic treatment of solvent-contaminated wastewater coming from the packaging sector under ambient temperatures. The performance of high rate EGSB reactors was investigated at $18{ }^{\circ} \mathrm{C}$ and $25^{\circ} \mathrm{C}$. In a first stage, reactors were operated under continuous supply of wastewater to determine the maximum organic load to be treated with high removal efficiencies. Later on, in order to simulate the discontinuous wastewater production associated with the shift work typically found in industry, reactors were operated under intermittent supply of substrate. The influence of the discontinuous supply of substrate on the performance of the process was studied.

\section{Materials and methods}

\subsection{Experimental set-up}

Experiments were performed in two laboratory-scale EGSB reactors (Fig. 1) with an effective volume of $4 \mathrm{~L}$ (internal diameter of $6.5 \mathrm{~cm}$, height of $120.5 \mathrm{~cm}$ ) and an overall volume of $19 \mathrm{~L}$, both operated in parallel. In this paper, organic loading rate is calculated on the basis of the effective volume. The synthetic wastewater was fed from 
the influent tank to the bottom of the reactor and the outlet stream took place via an outlet port located at $167 \mathrm{~cm}$ height. The sampling port was located in the recirculation pipe at $150 \mathrm{~cm}$ height, above the gas-liquid-solid separator device. The gas outlet was connected through rubber tubing to a gas seal with a solution of $\mathrm{NaOH}$ and bleach. The temperature was kept at desired values by means of an external jacket with water recirculation. External jacket temperature was controlled at $18{ }^{\circ} \mathrm{C}$ by thermostat cooling system (Polyscience SD15R-30, USA) and at $25^{\circ} \mathrm{C}$ by thermostat heating system (Julabo labortechnik GMBH F20-HC7, West Germany). Two peristaltic pumps (Watson-Marlow, USA) provided feeding and recirculation flow through the reactor, with the recirculation stream being the main flow; feeding flow from 5 to $14.4 \mathrm{l} \mathrm{d}^{-1}$ and recirculation flow from 30 to $41.7 \mathrm{l} \mathrm{h}^{-1}$. Both flows were combined before entering the reactor, up-flow velocity ranging from 9.2 to $12.8 \mathrm{~m} \mathrm{~h}^{-1}$.

\subsection{EGSB operation}

The reactors were inoculated with granular anaerobic sludge of a $786 \mathrm{~m}^{3} \mathrm{IC}$ reactor operated in the range of temperature between $22^{\circ} \mathrm{C}$ and $32{ }^{\circ} \mathrm{C}$ from the Font Salem brewery at El Puig, Spain. One of the reactors (R1) was maintained under psychrophilic temperature $\left(18^{\circ} \mathrm{C}\right)$ and the other (R2) was operated under sub optimal mesophilic conditions at $25{ }^{\circ} \mathrm{C}$ throughout the entire experimental period. During the start-up the reactors were operated for 4 months with increasing organic loading rates (OLR) of ethanol ranging from 6 to $31 \mathrm{~kg} \mathrm{COD} \mathrm{m}^{-3} \mathrm{~d}^{-1}$ in $\mathrm{R} 1$ and from 8.4 to $45 \mathrm{~kg}^{\mathrm{COD} \mathrm{m}} \mathrm{m}^{-3}$ in R2 (Table 1). The influent was buffered with $5 \mathrm{~g} \mathrm{NaHCO}_{3} \mathrm{l}^{-1}$ and supplemented with macro- and micro-nutrients as follows, in mg per g of chemical oxygen demand (COD) (unless otherwise noted): $\mathrm{NH}_{4} \mathrm{Cl}, 15.7 ;\left(\mathrm{NH}_{4}\right)_{2} \mathrm{HPO}_{4}, 5.6 ; \mathrm{KCl}, 6.1 ; \mathrm{CaCl}_{2} \cdot 2 \mathrm{H}_{2} \mathrm{O}, 146.7$ $\mathrm{mg} \mathrm{l}^{-1} ; \mathrm{MgCl}_{2} \cdot 6 \mathrm{H}_{2} \mathrm{O}, 334.5 \mathrm{mg} \mathrm{l}^{-1} ; \mathrm{FeCl}_{3} \cdot 6 \mathrm{H}_{2} \mathrm{O}, 0.4208 ; \mathrm{H}_{3} \mathrm{BO}_{3}, 0.1143 ; \mathrm{ZnSO}_{4} \cdot 7 \mathrm{H}_{2} \mathrm{O}$, 
0.0132; $\mathrm{CuCl}_{2} \cdot 2 \mathrm{H}_{2} \mathrm{O}, 0.0134 ; \mathrm{MnCl}_{2} \cdot 4 \mathrm{H}_{2} \mathrm{O}, 0.1441 ;(\mathrm{NH} 4)_{2} \mathrm{Mo}_{7} \mathrm{O}_{24} \cdot 4 \mathrm{H}_{2} \mathrm{O}, 0.0625$;

$\mathrm{Al}_{2} \mathrm{O}_{3}, 0.0595 ; \mathrm{CoCl}_{2} \cdot 6 \mathrm{H} 2 \mathrm{O}, 0.1615$; $\mathrm{NiSO}_{4} \cdot 6 \mathrm{H}_{2} \mathrm{O}, 0.0447$; EDTANa, 0.1; yeast extract, 7.5. Once high removal efficiencies were obtained at OLR higher than $30 \mathrm{~kg} \mathrm{COD} \mathrm{m}{ }^{-3}$ $\mathrm{d}^{-1}$, influent COD composition was changed to binary mixtures of ethanol and M2P (day 0 ). First, between days 0 and 29, a mixture of ethanol and M2P was applied in a mass ratio of 3:1; from this day until the end of operation, a mass ratio of $4: 1$ was applied.

From day 0 to day 90 the trial was divided into four different operational periods (C-I to C-IV) characterised by a change in the applied OLR (Table 1) and by continuous substrate supply (24 hours a day for 7 days a week). The experiment started by applying the two highest OLR (periods C-I and C-II), then OLR was lowered in order to determine the M2P removal rate at efficiency higher than 90\% (periods C-III and C-IV). From day 91 to day 119 both reactors were kept without wastewater supply in order to evaluate the influence of a long substrate interruption period that can occur at industrial facilities. Recirculation was also switched off. From day 120, OLRs were increased in a step-wise mode from 14.4 to $35.3 \mathrm{~kg} \mathrm{COD} \mathrm{m}^{-3} \mathrm{~d}^{-1}$ in $\mathrm{R} 1$ and from 2.7 to $34 \mathrm{~kg} \mathrm{COD} \mathrm{m}^{-3}$ $\mathrm{d}^{-1}$ in R2. Once high removal efficiencies were achieved, the wastewater supply was changed to intermittent feeding mode and a new experiment was started on day 205. The wastewater flow at industrial facilities shows patterns on a daily time scale related to manufacturing shift work, which is usually established from 1 to 3 shifts per day depending on factory production. In this study, 2 shifts per day were selected to evaluate the impact of intermittent feeding mode on the anaerobic process. The test under intermittent substrate supply was divided into three different periods (D-I to DIII), depending on a change of either feeding regime or the applied OLR (Table 1). In D-I the supply of wastewater was stopped during nights (organic supply during 16 hours 
a day for 7 days a week). In D-II the substrate supply was also removed during weekends (organic supply during 16 hours a day for 5 days a week), maintaining the same OLR. In D-III OLR was increased until $35 \mathrm{~kg} \mathrm{COD} \mathrm{m}^{-3} \mathrm{~d}^{-1}$ in both reactors. No wastewater was supplied during night or on weekends. During periods without organic supply, the recirculation pump was kept on to maintain the fluidisation of the granular sludge bed.

Samples were collected at a sampling port located in the recirculation pipe twice a week. In order to determine the transient response under intermittent feeding mode, samples were collected every two hours from the beginning of the supply of organic substrate until 10 hours later. In periods D-II and D-III, samples were collected on Mondays (after two days without wastewater supply) and on Thursdays (after resumption of wastewater supply after a night period). Biogas measurements were carried out at the same time as the samples were collected.

\subsection{Analytical methods}

COD, VFA, ammonium and phosphate concentrations were determined according to Standard Methods [17]. Effluent solvent content was ascertained by gas chromatography (Agilent GC 7890A, Spain) equipped with a flame ionisation detector (FID), whereby samples were separated on a Restek Rtx-VMS column (30 m long $\times$ $0.25 \mathrm{~mm}$ i.d. $\times 1.4 \mu \mathrm{m}$ particle size) and helium was used as the carrier gas (flow rate: $25 \mathrm{ml} \mathrm{min}^{-1}$ ). The samples were fitted with a split injector and the temperatures at the GC injection and detection ports were $190^{\circ} \mathrm{C}$ and $240{ }^{\circ} \mathrm{C}$, respectively and at oven a ramp temperature was used $\left(35^{\circ} \mathrm{C}\right.$ for $28 \mathrm{~min}$ then $10^{\circ} \mathrm{C} \mathrm{min}^{-1}$ to $110^{\circ} \mathrm{C}$ ). Biogas composition was analysed from $1 \mathrm{ml}$ samples using an Agilent gas chromatography 7890A series with a TDC detector, whereby samples were separated on Supelco 
columns Carbosieve S-II (1 m long x 1/8” i.d. x 2.1 mm SS) and SP-1700 (9 m long x 1/8” i.d. x $2.1 \mathrm{~mm}$ SS) connected in a series using helium as a mobile phase; oven and detector temperatures were $70{ }^{\circ} \mathrm{C}$ and $175^{\circ} \mathrm{C}$, respectively. A liquid displacement gasometer was used to measure biogas flow composed by a closed cylinder partially submerged in an open container of deionised water. Biogas was introduced into the column via the bottom. The calculation of biogas flow was made from measurements of the change in liquid height in column in a time period.

\subsection{Anaerobic batch assessments}

Biomass was sampled from the bioreactors at the end of the whole experimental period (day 263) to determine the biodegradability of ethanol and M2P. The tests were carried out at $18{ }^{\circ} \mathrm{C}$ and $25{ }^{\circ} \mathrm{C}$ in triplicate. Serum bottles (500 ml) were filled with medium and $1.9 \mathrm{~g}$ volatile suspended solids (VSS). The bottles were placed in an Automatic Methane Potential Test System (AMPTS II) (Bioprocess control, Sweden) where they were brought to the desired temperature and intermittently stirred (60 s on/60 s off) at $112 \mathrm{rpm}$. The medium consisted of a synthetic solvent wastewater consisting of $2.5 \mathrm{~g}$ $\mathrm{COD}^{-1}$ of either ethanol or M2P as substrates, buffered with $5 \mathrm{~g} \mathrm{NaHCO}_{3} \mathrm{l}^{-1}$ and fortified with macro- and micro-nutrients as follows, mineral composition (mg $\mathrm{l}^{-1}$ ): $\mathrm{NH}_{4} \mathrm{Cl}$, 39.3; $\left(\mathrm{NH}_{4}\right)_{2} \mathrm{HPO}_{4}, 14 ; \mathrm{KCl}, 15.2 ; \mathrm{CaCl}_{2} \cdot 2 \mathrm{H}_{2} \mathrm{O}, 147 ; \mathrm{MgCl}_{2} \cdot 6 \mathrm{H}_{2} \mathrm{O}, 332.5$; $\mathrm{FeCl}_{3} \cdot 6 \mathrm{H}_{2} \mathrm{O}, 1.052 ; \mathrm{H}_{3} \mathrm{BO}_{3}, 0.2858 ; \mathrm{ZnSO}_{4} \cdot 7 \mathrm{H}_{2} \mathrm{O}, 0.033 ; \mathrm{CuCl}_{2} \cdot 2 \mathrm{H}_{2} \mathrm{O}, 0.0335$; $\mathrm{MnCl}_{2} \cdot 4 \mathrm{H}_{2} \mathrm{O}, 0.3603 ;(\mathrm{NH} 4)_{2} \mathrm{Mo}_{7} \mathrm{O}_{24} \cdot 4 \mathrm{H}_{2} \mathrm{O}, 0.1563 ; \mathrm{Al}_{2} \mathrm{O}_{3}, 0.1488 ; \mathrm{CoCl}_{2} \cdot 6 \mathrm{H} 2 \mathrm{O}$, 0.4038; $\mathrm{NiSO}_{4} \cdot 6 \mathrm{H}_{2} \mathrm{O}, 0.1118$; EDTANa, 0.25 . The biogas produced in each vial passed through an individual vial containing an alkaline solution $(\mathrm{NaOH} 3 \mathrm{M})$ to retain $\mathrm{CO}_{2}$ and $\mathrm{H}_{2} \mathrm{~S}$, only allowing $\mathrm{CH}_{4}$ to reach the biomethane gas monitoring unit. Specific methanogenic activity (SMA) was evaluated as the maximum specific methane 
production rate and the biochemical methane potential (BMP) was determined as the final accumulated methane production per initial organic content of substrate.

\section{Results and discussion}

\subsection{Start-up with ethanol}

High COD removal efficiencies were obtained at the end of this period, up to $91 \%$ at 18 ${ }^{\circ} \mathrm{C}(\mathrm{R} 1)$ and $98 \%$ at $25^{\circ} \mathrm{C}(\mathrm{R} 2)$, with applied OLR of 20 and $30 \mathrm{~kg} \mathrm{COD} \mathrm{m}^{-3} \mathrm{~d}^{-1}$ in R1 and R2, respectively (Fig. 2A). During this period, average biogas production of both

reactors was $0.336 \mathrm{~m}^{3}$ biogas $\mathrm{kg}^{-1} \mathrm{COD}_{\text {removed }}$ (data not shown). Successful start-up was observed for both reactors applying as sole organic carbon source ethanol. The obtained removal rate at sub-optimal mesophilic conditions $\left(\mathrm{R} 2,25^{\circ} \mathrm{C}\right)$ was similar to literature values. For example, Kato et al. [18] were able to treat an OLR of $32.4 \mathrm{~kg}$ COD m$^{-3} \mathrm{~d}^{-1}$ in an EGSB reactor operated at $30^{\circ} \mathrm{C}$ using ethanol and VFA as organic carbon source. The lowest removal rate in $\mathrm{R} 1\left(18^{\circ} \mathrm{C}\right)$ shows the decrease on the biodegradation rate of the mesophilic inoculum on its adaptation to lower temperatures. The adverse influence of the low temperature on the performance will be observed during the whole experimentation period.

3.2. Operation with continuous supply of wastewater

\subsubsection{Period C-I}

The addition of M2P to resulted in an initial decrease in COD removal efficiencies (Fig. 2A). By day 14, the COD removal efficiency was $69 \%$ in $\mathrm{R} 1$ and $76 \%$ in $\mathrm{R} 2$ at OLR of 33 and $46 \mathrm{~kg} \mathrm{COD} \mathrm{m}^{-3} \mathrm{~d}^{-1}$, respectively. Gas chromatography analysis showed the complete degradation of ethanol and a small degradation of M2P. M2P removal efficiency was slowly increasing up to $30.3 \%$ and $34.1 \%$ measured on day 23 for R1 
and R2, respectively (Fig. 2B). The slight increase in COD removal efficiency registered along this period was caused by the retarded adaptation of biomass to M2P as organic carbon source, as suggested by the progressive decrease of M2P-COD effluent concentration (Fig. 3A). Although M2P degrading enzymes are not still characterized, literature indicates that the generally accepted mechanisms for anaerobic glycol ether cleavage are dioldehydratase-catalyzed reactions. The whole process includes a double $\mathrm{H} / \mathrm{OH}$ interchange (transhydroxylation) resulting to the gem-diol [19]. This intermediate rapidly collapses to the carbonyl or keto group $\mathrm{C}=\mathrm{O}$. This mechanism starting by the shift of the terminal $\mathrm{OH}$ group is also postulated for the anaerobic degradation of polyethylene glycol (PEG); and Kawai [20] hypotheses that intracellular mechanism of polypropylene glycol (with same terminal $\mathrm{OH}$ group that $\mathrm{M} 2 \mathrm{P}$ ) is the same as that of PEG. The expected products in case of the ether cleavage of M2P would be acetone or propionaldehyde plus methanol. It can be inferred that some time was required to develop the ether-cleaving enzymes to degrade M2P in the EGSB reactors.

Methane yield was kept similar in both reactors, with values between 0.178 and 0.295 $\mathrm{m}^{3}$ methane $\mathrm{kg}^{-1} \mathrm{COD}_{\text {removed }}$ in R1 and between 0.187 and $0.362 \mathrm{~m}^{3}$ methane $\mathrm{kg}^{-1}$ $\mathrm{COD}_{\text {removed }}$ in R2 (Fig 3B). VFA concentration in the effluent was lower than $7.3 \mathrm{mg}$ $\mathrm{CH}_{3} \mathrm{COOH}{ }^{-1}$ in $\mathrm{R} 2$ except on day 21. At lower temperature (R1), higher VFA concentrations were obtained (92.4-134.2 $\mathrm{mg} \mathrm{CH}_{3} \mathrm{COOH} \mathrm{l}^{-1}$ ) (Fig 3C). This corroborates the lowest degradation rate of methanogenic bacteria at the lowest temperature.

\subsubsection{Period C-II}

In period C-II the OLR of M2P was kept in similar values than in period C-I. In order to stimulate the anaerobic process, the OLR was increased by increasing the ethanol:M2P 
mass ratio to 4:1. Outlet M2P concentration was found to decrease during period C-II in both reactors until reaching $1328 \mathrm{mg} \mathrm{COD} \mathrm{l}^{-1}$ in $\mathrm{R} 1$ and $282 \mathrm{mg} \mathrm{COD} \mathrm{l}^{-1}$ in R2 on day 44 (Fig. 3A). These results show that an acclimatisation period of 44 days in R1 and 34 days in R2 were needed in order to remove more than 50\% of M2P, temperature impacts on the adaptation time to degrade low biodegradable solvents as M2P. Other authors also reported a lag phase for removing solvents in wastewater. For example, Scully et al. [4] indicated that 26 days were needed before the degradation of phenol at $15^{\circ} \mathrm{C}$. The maximum removal rate of M2P for the whole study was achieved on day 44 : 11.3 $\mathrm{kg} \mathrm{COD} \mathrm{m}{ }^{-3} \mathrm{~d}^{-1}$ at $25{ }^{\circ} \mathrm{C}(\mathrm{R} 2)$ which culminates in a total COD removal efficiency in $\mathrm{R} 2$ up to $98 \%$ (Fig. 2A). On day 44 at $18^{\circ} \mathrm{C}$ (R1), the removal rate of M2P was as low as $4.4 \mathrm{~kg}$ COD m $\mathrm{m}^{-3} \mathrm{~d}^{-1}$. Concentration of VFA in R1 oscillated between values from 83.5 to $198.2 \mathrm{mg} \mathrm{CH}_{3} \mathrm{COOH} \mathrm{l}^{-1}$, while concentration of VFA in R2 effluent was maintained at values as low as $7.7 \mathrm{mg} \mathrm{CH}_{3} \mathrm{COOH} \mathrm{l}{ }^{-1}$ (day 44) (Fig. 3C). The growth of methanogens proceeds much slower at low temperatures, methanogenesis was the ratelimiting step in solvent degradation under psychrophilic conditions due to the rates of VFA production and consumption are not well balanced.

\subsubsection{Period C-III}

As both reactors were not able to fully remove M2P during period C-II, the inlet solvent concentration was diluted to decrease OLR to 65\% (Table 1). In this period, total COD removal efficiencies higher than 94\% were achieved in both reactors (Fig. 2A). The decrease in the OLR of M2P caused an increase in its removal efficiency, achieving values higher than 73\% for R1 and 90\% for R2 during the entire period C-III (Fig. 2B). From day 57, chromatography analysis indicated that M2P outlet concentration was maintained lower than $744 \mathrm{mg} \mathrm{COD} \mathrm{l}^{-1}$ in R1 and $330 \mathrm{mg} \mathrm{COD} \mathrm{l}^{-1}$ in R2 (Fig. 3A), 
During this period, methane yield in both reactors was more stable and higher than in periods C-I and C-II, with values ranging from 0.273 to $0.339 \mathrm{~m}^{3}$ methane $\mathrm{kg}^{-1}$ $\mathrm{COD}_{\text {removed }}$ in R1 and from 0.258 to $0.37 \mathrm{~m}^{3}$ methane $\mathrm{kg}^{-1} \mathrm{COD}_{\text {removed }}$ in R2 (Fig. 3B). The improvement of methane yield was accompanied by a decrease of the concentration of VFA in the effluent of reactor R1 $\left(18^{\circ} \mathrm{C}\right)$, with values between 51 and $137 \mathrm{mg}$

$\mathrm{CH}_{3} \mathrm{COOH}{ }^{-1}$ (Fig. 3C). These results showed the ultimate adaptation of the biomass to degrade M2P at $18{ }^{\circ} \mathrm{C}$ with a removal rate of M2P of $4.8 \mathrm{~kg} \mathrm{COD} \mathrm{m}^{-3} \mathrm{~d}^{-1}$ achieved on day 72.

\subsubsection{Period C-IV}

During period C-IV an increase of approximately $20 \%$ of the OLR was applied to R1 and R2. The reactors were able to show a good performance in terms of total COD removal, with values of up to $94 \%$ in R1 and 97\% in R2 (Fig. 2A). M2P removal efficiency was kept at similar values to those in the previous stage, achieving values higher than 76\% in R1 and 87\% in R2 (Fig. 2B). Accordingly, M2P concentration in the effluent was kept at low values: less than $578 \mathrm{mg} \mathrm{COD} \mathrm{l}^{-1}$ in $\mathrm{R} 1$ and $386 \mathrm{mg} \mathrm{COD} \mathrm{l}^{-1}$ in R2 (Fig. 3A). The low concentration of VFA and the stable methane yield was kept in both reactors indicating the stability of the anaerobic process. It can be treated an OLR of M2P up to $9.3 \mathrm{~kg} \mathrm{COD} \mathrm{m}^{-3} \mathrm{~d}^{-1}$ at $25^{\circ} \mathrm{C}$, while an OLR lower than $33 \%$ can be treated at $18{ }^{\circ} \mathrm{C}$. The adverse influence of the low temperature on the degradation of ethanol and M2P is similar. For both solvents the OLR to keep high removal efficiencies is about one third lower at $18{ }^{\circ} \mathrm{C}$ than at $25^{\circ} \mathrm{C}$. These results showed the feasibility of EGSB reactors to remove M2P from binary mixtures with ethanol under continuous operation at sub-optimal mesophilic and psychrophilic temperatures. It can be hypothesized that the removal of M2P is kinetically slower than that of ethanol due to 
the complex metabolisation of M2P, which was postulated as an enzymatic ether cleavage followed by the anaerobic biodegradation of products such as methanol and acetone or propionaldehyde.

\subsection{Discontinuous operation with wastewater containing ethanol-M2P}

From day 91 to day 119 the EGSB reactors were kept without wastewater supply and no recirculation flow. Total COD removal efficiency after resumption of the operation on day 120 was lower than that measured in periods C-III and C-IV, as depicted in Fig. 4A. Anaerobic reactors were able to remove ethanol from the first day onwards but not M2P. In R2, the OLR was decreased on day 127 and was progressively increased until day 155 in order to promote the biodegradation of M2P. After about 40 days of feeding resumption, M2P removal efficiencies were kept mostly in values higher than $95 \%$ in R2 (Fig. 4B). At $18^{\circ} \mathrm{C}$ (R1) 10 days more were required to achieve similar M2P removal efficiencies. This result shows the lost of the enzymatic activity of the anaerobic biomass to degrade M2P after 30 days without supply of the substrate, thus suggesting that for the industrial degradation of M2P is advisable not to shift the ink composition regarding the presence M2P.

After the re-acclimatization of the reactors to remove M2P, the testing of the process under intermittent feeding was initiated, firstly (period D-I) with wastewater supply of 16 hours a day for 7 days a week, and followed by the stopping of wastewater supply also during weekends (periods D-II and D-III). By working at an OLR of $30 \mathrm{~kg} \mathrm{COD} \mathrm{m}^{-}$ ${ }^{3} \mathrm{~d}^{-1}$ (periods D-I and D-II), a stable performance of both EGSB reactors was found. Ethanol was completely removed and M2P removal rate ranged between 5.5 and $6.4 \mathrm{~kg}$ COD m $\mathrm{m}^{-3} \mathrm{~d}^{-1}$ (removal efficiencies varied from $84 \%$ and $97 \%$ ). These values are quite similar to those obtained during continuous supply of wastewater when similar OLR 
were applied. The short-time interruptions associated to night or weekend periods does not seem have an adverse impact to the solvent degradation by working at total OLR of $30 \mathrm{~kg} \mathrm{COD} \mathrm{m}^{-3} \mathrm{~d}^{-1}$. Nadais et al. [21] also observed that an intermittent operation of cycles of $48 \mathrm{~h}$ feed/48 h feedless resulted in same COD removal as with continuous operation in an UASB with a load of $14 \mathrm{~kg} \mathrm{COD} \mathrm{m}^{-3} \mathrm{~d}^{-1}$ of dairy wastewater at $35^{\circ} \mathrm{C}$. The applied OLR was increased until $35 \mathrm{~kg} \mathrm{COD} \mathrm{m}^{-3} \mathrm{~d}^{-1}$ in both reactors on day 242. Although M2P removal efficiency was kept in values higher than 86\% for R1 and 95\% for R2, granule disintegration was observed at the end of the trial; the well-settled and spherical morphology granules changed to a flocculent morphotype. During this period weekly accumulations of VFA, with concentrations higher than $100 \mathrm{mg} \mathrm{CH}_{3} \mathrm{COOH} \mathrm{l}{ }^{-1}$ were observed. The intermittent supply of organic substrate caused a deterioration of the methanogenesis activity at $25^{\circ} \mathrm{C}$ in comparison with that reported under continuous supply of wastewater under similar OLR (period C-III). This demonstrated that the intermittent organic supply of substrate can influence negatively on the anaerobic biodegradation when high loads are applied; thus indicating the importance of evaluate the impact that the pattern of the wastewater generation has on the treatment of solventbased wastewater.

\subsubsection{Transient response under discontinuous operation}

The transient response of the bioreactors after the resumption of wastewater supply (after 8 hours or after a whole weekend without feeding) was studied from periods D-I to D-III. Methane yield and VFA concentration in the effluent were monitored every two hours, since the organic substrate resumption (time=0) until 10 hours later. Methane yield and VFA concentration profiles are plotted in Fig. 5. In period D-I (substrate supply 16 hours a day for 7 days a week), an increasing methane yield was measured 
during the first 6 hours after resumption of wastewater supply in both reactors; then, a pseudo-stable methane production was reached (Fig. 5A and B). The VFA concentration in the effluent was less than $74 \mathrm{mg} \mathrm{CH}_{3} \mathrm{COOH}{ }^{-1}$ after the first 2 hours, showing a good start of the methanogenic activity in both reactors after 8 hours without wastewater supply (Fig. 5C and D). Similar methane yield and VFA concentration profiles were measured on Thursdays in period D-II (8 hours without wastewater supply) in both reactors, showing the fast recovery and stability of reactors performance after a substrate stop of 8 hours. This is in agreement with the high removal efficiencies reported during periods D-I and D-II.

On Monday, after 56 hours without substrate supply (weekend stops), a decline in methane production was observed in both reactors. In 10 hours of monitoring it was not possible to reach the same metabolic activity measured after a substrate stop of 8 hours, with a methane yield reduction ranging between 15 and 30\% in comparison to that measured during the first substrate supply hours on Thursdays in period D-II, evidencing that periods higher than 48 hours affect negatively on the methanogenic activity. In period D-III, as a consequence of an increase in the total OLR until $35 \mathrm{~kg}$ COD $\mathrm{m}^{-3} \mathrm{~d}^{-1}$, an accumulation of VFA concentration was observed on Thursdays (8 hours without substrate supply); reactors were not able to reduce VFA concentrations in less than 10 hours, suggesting overloading of the reactors. It can be assumed that the overloading of the reactors since day 242 is the cause for the degranulation of the sludge that occurs in day 263. After 56 hours without substrate supply, this instantaneous VFA accumulation was not observed; biomass degraded the accumulated substrate inside granules during the weekend, making the system more ready to absorb new loads on Monday. 


\subsection{Anaerobic batch profiles of solvents}

Anaerobic batch assays of the sludge from bioreactors were carried out at the end of the trial at $25^{\circ} \mathrm{C}$ and $18{ }^{\circ} \mathrm{C}$, using ethanol or M2P as the sole organic carbon source. Results are summarized in Table 2. As it was expected from EGSB results, SMA and BMP values were lower at psychrophilic conditions for both substrates. Van den Berg [22] observed a similar difference: SMA values three times lower at psychrophilic temperature $\left(18^{\circ} \mathrm{C}\right)$ than those obtained at mesophilic temperature $\left(25^{\circ} \mathrm{C}\right)$ using as inoculum mesophilic biomass $\left(35^{\circ} \mathrm{C}\right)$ and acetic acid as a substrate. The low performance at $18{ }^{\circ} \mathrm{C}$ of our study could indicate that the establishment of a psychrophilic community did not materialise in R1, remaining a psychrotolerant mesophilic community during almost 9 months of EGSB reactor operation. Other authors found also that a psychrotolerant mesophilic community from mesophlilic inoculum was developed at $15{ }^{\circ} \mathrm{C}$ during the anaerobic degradation of mixtures of solvents like ethanol and toluene [5], ethanol and phenol [4], ethanol and methanol or propanol [3]. Methane production in the batch assays ran with M2P as unique carbon source started after a lag phase of 31 and 6 days at $18^{\circ} \mathrm{C}$ and $25^{\circ} \mathrm{C}$ despite using the sludge of EGSB reactors as inoculum. It seems that the presence of ethanol could play an important role as a co-substrate to favor the metabolic activity evolved on the enzymatic ether cleavage during the degradation of glycol ether and the degradation of formed intermediate products. Other authors [23] also found a lag phase of nearly 1 month in SMA test at $30^{\circ} \mathrm{C}$ for phenol degradation with granular UASB sludge acclimatized to phenol as inoculum.

\section{Conclusions}


This is the first study on the removal of M2P, a solvent used in the packaging sector, by an EGSB reactor with a continuous and discontinuous supply of a binary mixture of M2P and ethanol, demonstrating that granular anaerobic treatment is a feasible technology for the removal of this solvent at sub-optimal mesophilic and psychrophilic temperatures. Starting with a biomass adapted to ethanol, a change in substrate composition from ethanol to a mixture of ethanol and M2P resulted in an adaptation period of approximately 45 days at $25^{\circ} \mathrm{C}$. At $18^{\circ} \mathrm{C}$, the adaptation period of biomass lasted for more than two months, showing the minor degradation velocity at lower temperatures. The long adaptation periods are related to the lack of enzymes for ether cleavage of M2P in the inoculum; these enzymes appear slowly during the EGSB operation. Substrate supply interruptions (for 8 hours a day or 56 hours a week) resulted in lower removal rate of M2P. At $25^{\circ} \mathrm{C}$, the shift to a discontinuous supply of substrate caused a decline in the maximum M2P removal rate from $9 \mathrm{~kg} \mathrm{COD} \mathrm{m}^{-3} \mathrm{~d}^{-1}$ to $7.2 \mathrm{~kg}$ COD $\mathrm{m}^{-3} \mathrm{~d}^{-1}$. A fast recovery of methanogenic activity was observed after wastewater resumption following 8 hours without wastewater supply, while after 56 hours without substrate supply, methane yield decreased by between 15 and 30\% when wastewater supply was cut off for 56 hours. This shows the adverse influence on the anaerobic process for cyclic periods of more than 2 days without substrate. The combination of organic overload and daily interruption in substrate supply resulted in unstable reactor performance associated with a decline on the methanogenic activity, as evidenced in the increase of VFA concentrations and the loss of granulation. The long re-acclimatization period to degrade M2P after 30-days stop demonstrates the fast lost of the enzymatic activity when biomass is not exposed to this solvent.

\section{Acknowledgements}


This project has received funding from the European Union’s Seventh Framework Programme for research, technological development and demonstration under grant agreement $n^{\circ}$ 284949. Financial support from Ministerio de Economía y Competitividad (Project CTM2014-54517) and Generalitat Valenciana (PROMETEO/2013/053), Spain, is also acknowledged. C. Lafita has a FPI grant from Ministerio de Economía y Competitividad, Spain. 


\section{References}

1. Aydin AF, Ersahin ME, Dereli RK, Sarikaya HZ, Ozturk I (2010) Long-term anaerobic treatability studies on opium alkaloids industry effluents. J Environ Sci Health Part A-Toxic/Hazard Subst Environ Eng 45:192-200

\section{European Commision (2006) European Union Risk Assessment Report.}

3. Enright A, McHugh S, Collins G, O’Flaherty V (2005) Low-temperature anaerobic biological treatment of solvent-containing pharmaceutical wastewater. Water Res 39:4587-4596

4. Scully C, Collins G, O'Flaherty V (2006) Anaerobic biological treatment of phenol at 9.5-15 degrees $C$ in an expanded granular sludge bed (EGSB)-based bioreactor. Water Res 40:3737-3744

5. Enright A, Collins G, O’Flaherty V (2007) Low-temperature anaerobic biological treatment of toluene-containing wastewater. Water Res 41:1465-1472

6. van Lier JB (2008) High-rate anaerobic wastewater treatment: diversifying from endof-the-pipe treatment to resource-oriented conversion techniques. 57:1137-1148

7. del Pozo R, Diez V, Salazar G (2002) Start-up of a pilot-scale anaerobic fixed film reactor at low temperature treating slaughterhouse wastewater. 46:215-221

8. Siggins A, Enright A, O'Flaherty V (2011) Temperature dependent (37-15 degrees C) anaerobic digestion of a trichloroethylene-contaminated wastewater. Bioresour Technol 102:7645-7656

9. Rajeshwari KV, Balakrishnan M, Kansal A, Lata K, Kishore VVN (2000) State-ofthe-art of anaerobic digestion technology for industrial wastewater treatment. 4:135-156

10. Lettinga G, Rebac S, Zeeman G (2001) Challenge of psychrophilic anaerobic wastewater treatment. Trends Biotechnol 19:363-370

11. Kashyap DR, Dadhich KS, Sharma SK (2003) Biomethanation under psychrophilic conditions: a review. Bioresour Technol 87:147-153

12. Kettunen RH, Rintala JA (1997) The effect of low temperature (5-29 degrees C) and adaptation on the methanogenic activity of biomass. Appl Microbiol Biotechnol 48:570576

13. Zoutberg GR, deBeen P (1997) The Biobed(R) EGSB (expanded granular sludge bed) system covers shortcomings of the upflow anaerobic sludge blanket reactor in the chemical industry. 35:183-188 
14. Seghezzo L, Zeeman G, van Lier JB, Hamelers HVM, Lettinga G (1998) A review: The anaerobic treatment of sewage in UASB and EGSB reactors. Bioresour Technol 65:175-190

15. Leitao RC, van Haandel AC, Zeeman G, Lettinga G (2006) The effects of operational and environmental variations on anaerobic wastewater treatment systems: A review. Bioresour Technol 97:1105-1118

16. Coelho NM, Rodrigues AA, Arroja LM, Capela IF (2007) Effect of non-feeding period length on the intermittent operation of UASB reactors treating dairy effluents. Biotechnol Bioeng 96:244-249

17. American Public Health Association (1998) Standard methods for the examination of water and wastewater.

18. Kato M, Field J, Versteeg P, Lettinga G (1994) Feasibility of expanded granular sludge bed reactors for the anaerobic treatment of low-strength soluble wastewaters. Biotechnol Bioeng 44:469-479

19. Speranza G, Mueller B, Orlandi M, Morelli C, Manitto P, Schink B (2002) Mechanism of anaerobic ether cleavage - Conversion of 2-phenoxyethanol to phenol and acetaldehyde by Acetobacterium sp. J Biol Chem 277:11684-11690

20. Kawai F (2002) Microbial degradation of polyethers. Appl Microbiol Biotechnol 58:30-38

21. Nadais H, Capela I, Arroja L, Duarte A (2005) Optimum cycle time for intermittent UASB reactors treating dairy wastewater. Water Res 39:1511-1518

22. van den Berg L (1977) Effect of temperature on growth and activity of a methanogenic culture utilizing acetate. Can J Microbiol 23:898-902

23. Upadhyay U, Kumar P, Mehrotra I (2008) Anaerobic degradation of benzoate: Batch studies. Bioresour Technol 99:6861-6865 
2 Table 1 Summary of operating conditions and treatment efficiencies for the two EGSB reactors R1 and R2.

\begin{tabular}{|c|c|c|c|c|c|c|c|c|c|c|}
\hline Period & & $\begin{array}{c}\text { Start-up } \\
\text { period }\end{array}$ & C-I & C-II & C-III & C-IV & $\begin{array}{c}\text { Re-start } \\
\text { period }\end{array}$ & D-I & D-II & D-III \\
\hline & Days & $-119--1$ & $0-29$ & $30-47$ & $48-79$ & $80-90$ & $120-204$ & 205-231 & $232-241$ & $242-263$ \\
\hline & Feeding regime & & & ntinuous & & & Continuous & 16h/7d-week & 16h/5d-week & 16h/5d-week \\
\hline \multirow{5}{*}{$\begin{array}{c}\mathrm{R} 1 \\
\left(18^{\circ} \mathrm{C}\right)\end{array}$} & Influent COD, g COD l ${ }^{-1}$ & $6.9-12.5$ & 13 & 14 & 14 & 14 & $7.5-14.1$ & 13 & 13 & 15 \\
\hline & Influent M2P, g COD $\mathrm{l}^{-1}$ & 0 & 3.4 & 2.5 & 2.5 & 2.5 & $1.6-3$ & 2.7 & 2.7 & 3.2 \\
\hline & OLR, kg COD m $\mathrm{m}^{-3} \mathrm{~d}^{-1}$ & $6-31$ & 33 & 36 & 24 & 29 & 14.4-35.3 & 30 & 30 & 35 \\
\hline & M2P OLR, kg COD m ${ }^{-3} \mathrm{~d}^{-1}$ & 0 & 8.6 & 7.4 & 5.1 & 6.4 & $3-7.4$ & 6.6 & 6.6 & 7.6 \\
\hline & $\mathrm{v}_{\mathrm{up}}, \mathrm{m} \mathrm{h}^{-1}$ & 9.2 & 9.2 & 12.7 & 12.7 & 12.7 & 12.7 & 12.7 & 12.8 & 12.8 \\
\hline \multirow{5}{*}{$\begin{array}{c}\mathrm{R} 2 \\
\left(25^{\circ} \mathrm{C}\right)\end{array}$} & Influent COD, g COD l ${ }^{-1}$ & $5.9-12.5$ & 12.5 & 14.5 & 14 & 14 & $7-14.7$ & 13 & 13 & 15 \\
\hline & Influent M2P, g COD l ${ }^{-1}$ & 0 & 3.3 & 3.1 & 2.9 & 2.9 & $1.5-3.1$ & 2.7 & 2.7 & 3.2 \\
\hline & OLR, kg COD m ${ }^{-3} \mathrm{~d}^{-1}$ & $8.4-45$ & 46 & 53 & 34 & 43 & $2.7-34$ & 30 & 30 & 35 \\
\hline & M2P OLR, kg COD m $\mathrm{m}^{-3} \mathrm{~d}^{-1}$ & 0 & 11.8 & 11 & 7.4 & 9.3 & $0.6-7.1$ & 6.6 & 6.6 & 7.6 \\
\hline & $\mathrm{v}_{\mathrm{up}}, \mathrm{m} \mathrm{h}^{-1}$ & 9.1 & 9.2 & 12.8 & 12.7 & 12.7 & 12.6 & 12.7 & 12.8 & 12.8 \\
\hline
\end{tabular}


Table 2 Specific methanogenic activity $\left(\mathrm{ml} \mathrm{CH}_{4} \mathrm{~g} \mathrm{VSS}^{-1} \mathrm{~d}^{-1}\right)$, biochemical methane potential (ml $\mathrm{CH}_{4} \mathrm{~g} \mathrm{COD}^{-1}$ ) and lag phase (days) of sludge from bioreactors at the end of the trial.

\begin{tabular}{llccc}
\cline { 3 - 5 } & & $\begin{array}{c}\text { SMA, } \\
\mathrm{ml} \mathrm{CH}_{4} \mathrm{gVSS}^{-1} \mathrm{~d}^{-1}\end{array}$ & $\begin{array}{c}\text { BMP, } \\
\mathrm{ml} \mathrm{CH}_{4} \mathrm{~g} \mathrm{COD}^{-1}\end{array}$ & $\begin{array}{c}\text { Lag phase, } \\
\text { days }\end{array}$ \\
\hline \multirow{3}{*}{ Ethanol } & $18^{\circ} \mathrm{C}$ & $60.1 \pm 2.5$ & $266.2 \pm 6.3$ & 0 \\
\hline \multirow{3}{*}{ M2P } & $25^{\circ} \mathrm{C}$ & $214.5 \pm 6.2$ & $330.4 \pm 3.6$ & 0 \\
\hline & $18^{\circ} \mathrm{C}$ & $7.8 \pm 0.1$ & $232.7 \pm 6.5$ & $31 \pm 1.3$ \\
\hline
\end{tabular}




\section{Figure Captions}

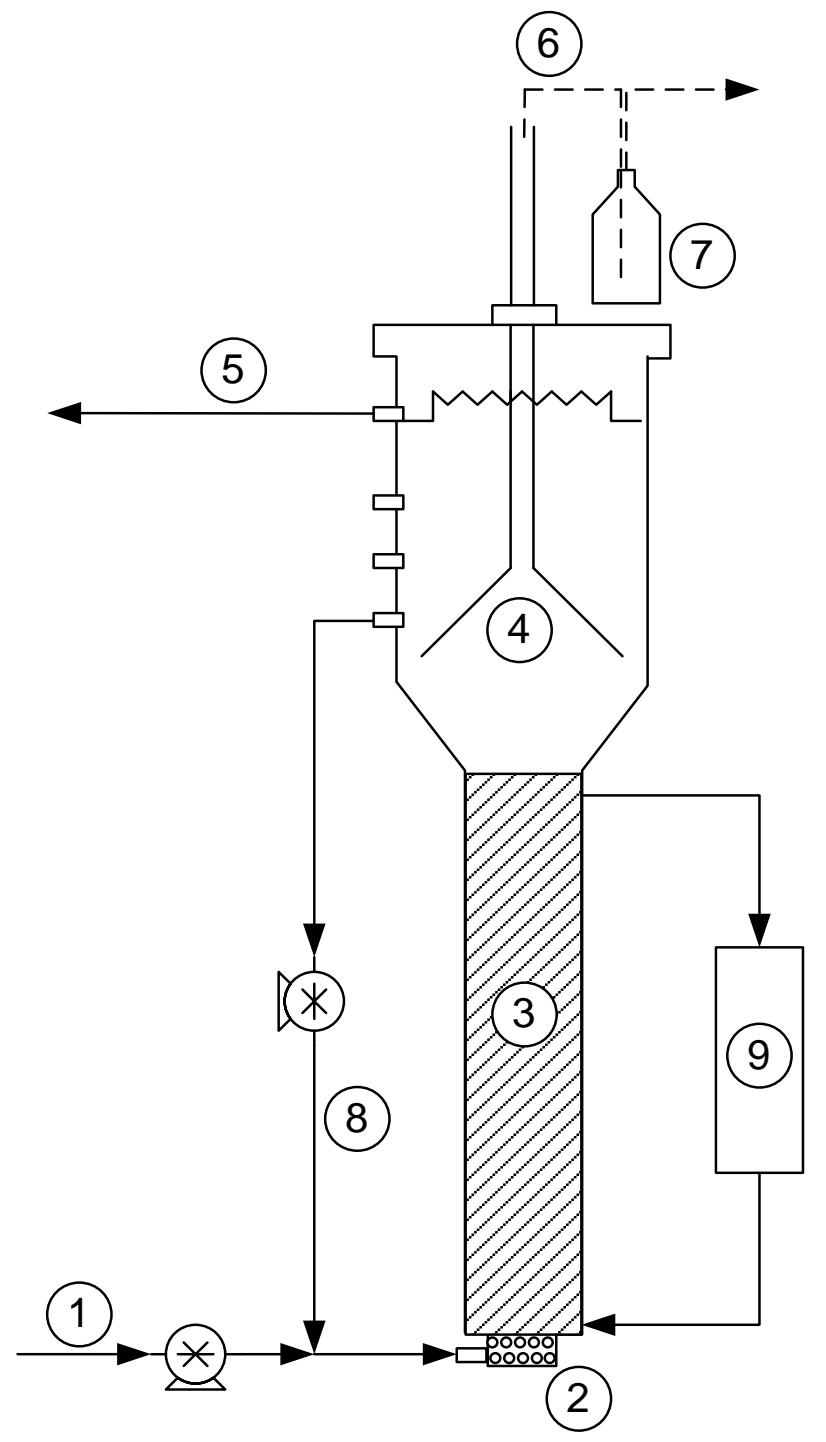

Fig 1 Schematic diagram of the laboratory scale EGSB reactors used in this study. 1, feed; 2, glass balls; 3, effective volume; 4, gas-liquid-solid separator; 5, effluent from EGSB reactor; 6, biogas; 7, gas seal; 8, effluent recirculation; 9, cooling/heating bath circulator 

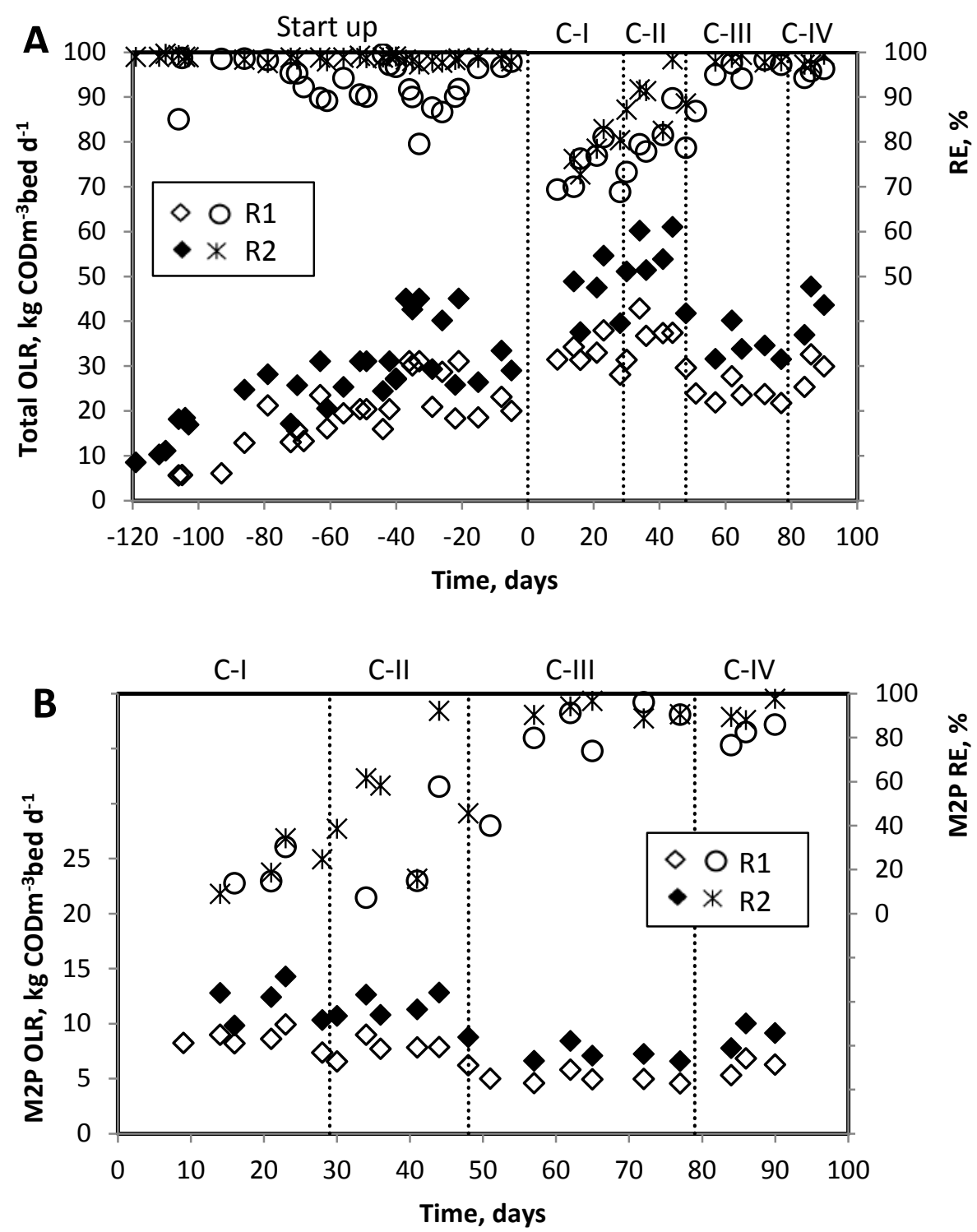

Fig 2 Evolution of the performance of both reactors (R1 and R2) under continuous wastewater supply. (a) total OLR and COD removal efficiency; (b) M2P OLR and M2P removal efficiency 

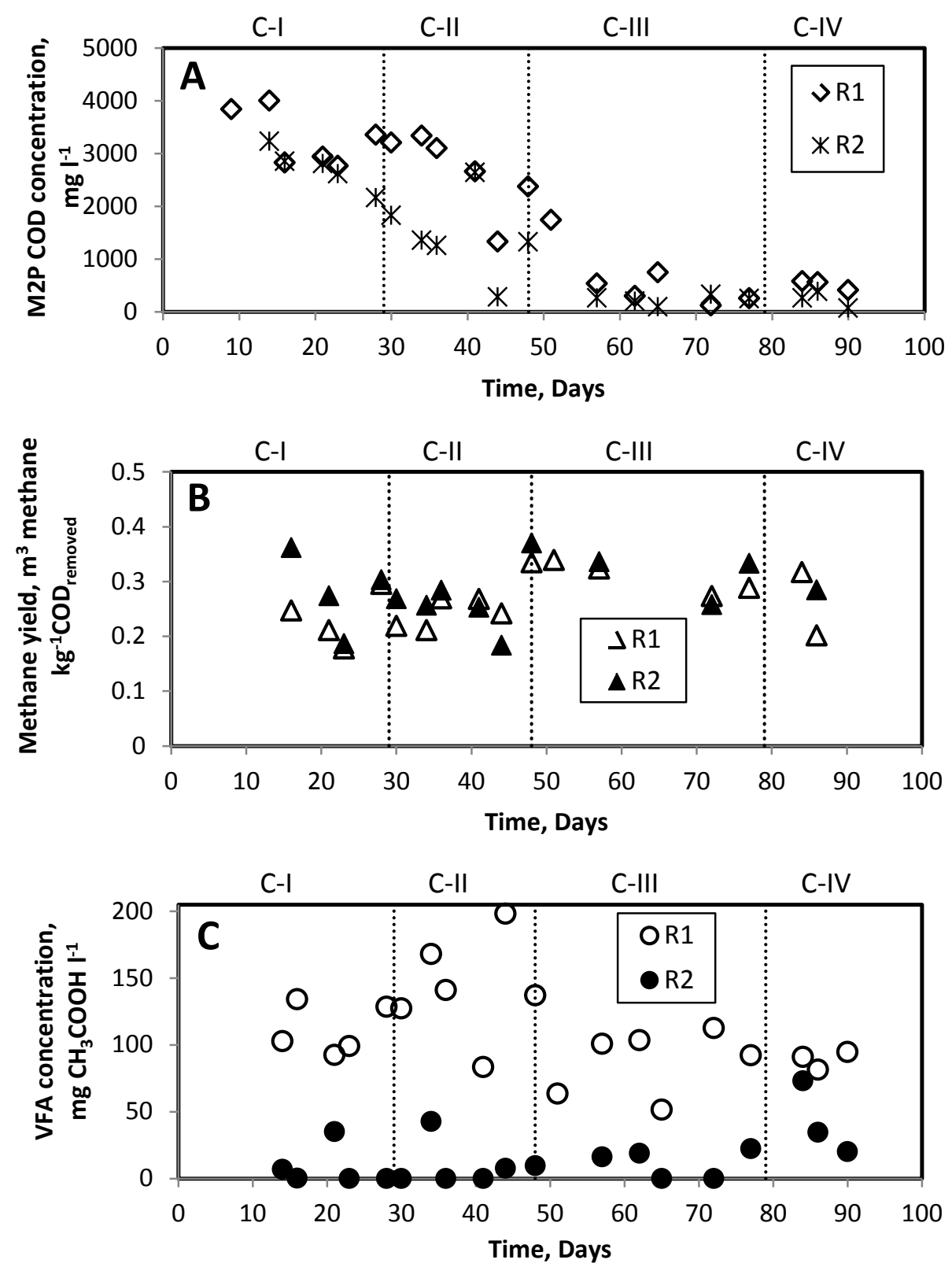

Fig 3 Evolution of the performance of both reactors (R1 and R2) under continuous wastewater supply. (a) effluent M2P COD concentration; (b) methane yield; (c) VFA concentration 

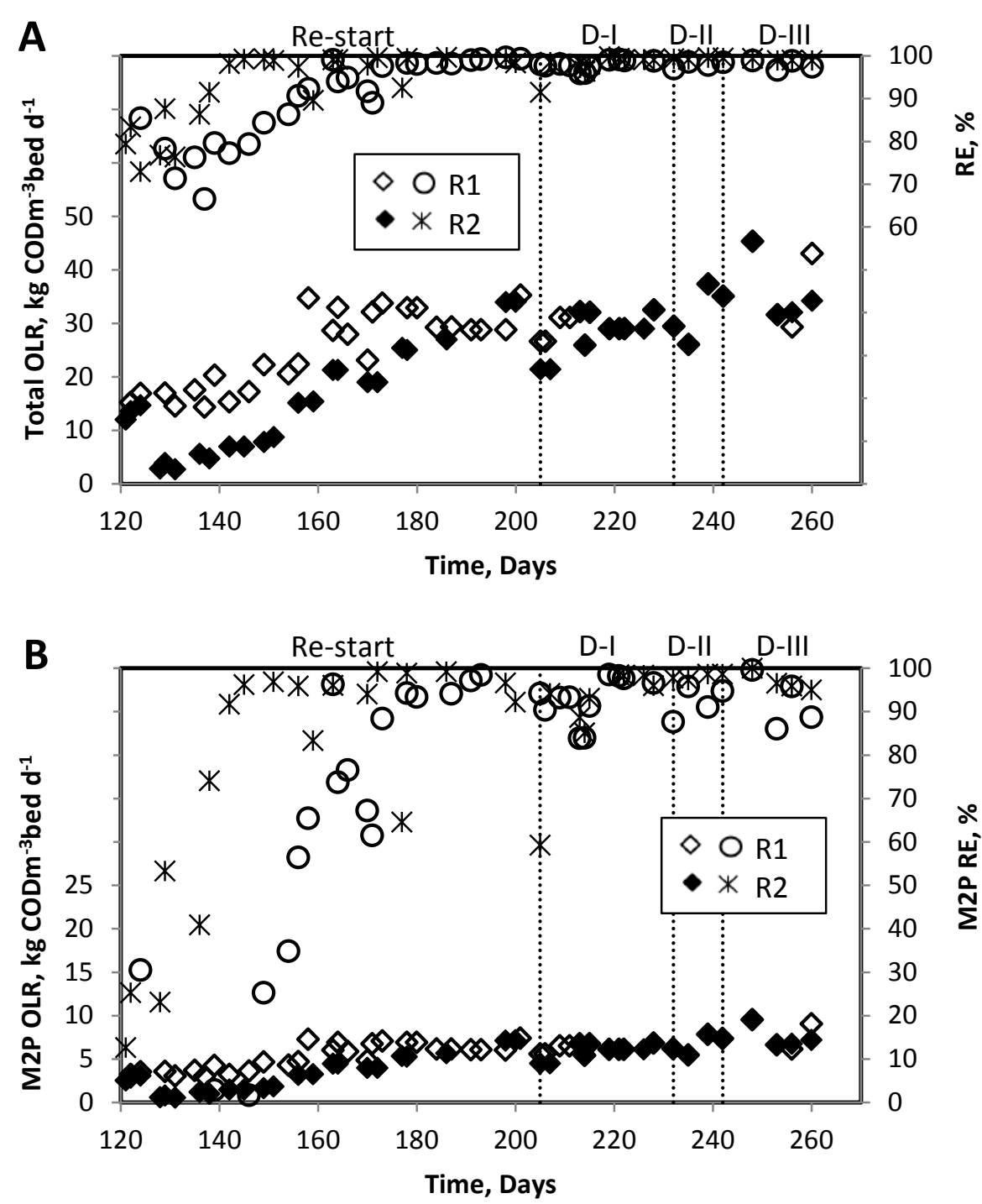

Fig 4 Evolution of the performance of both reactors under intermittent wastewater supply. (a) Total OLR and COD removal efficiency; (b) M2P OLR and M2P removal efficiency 

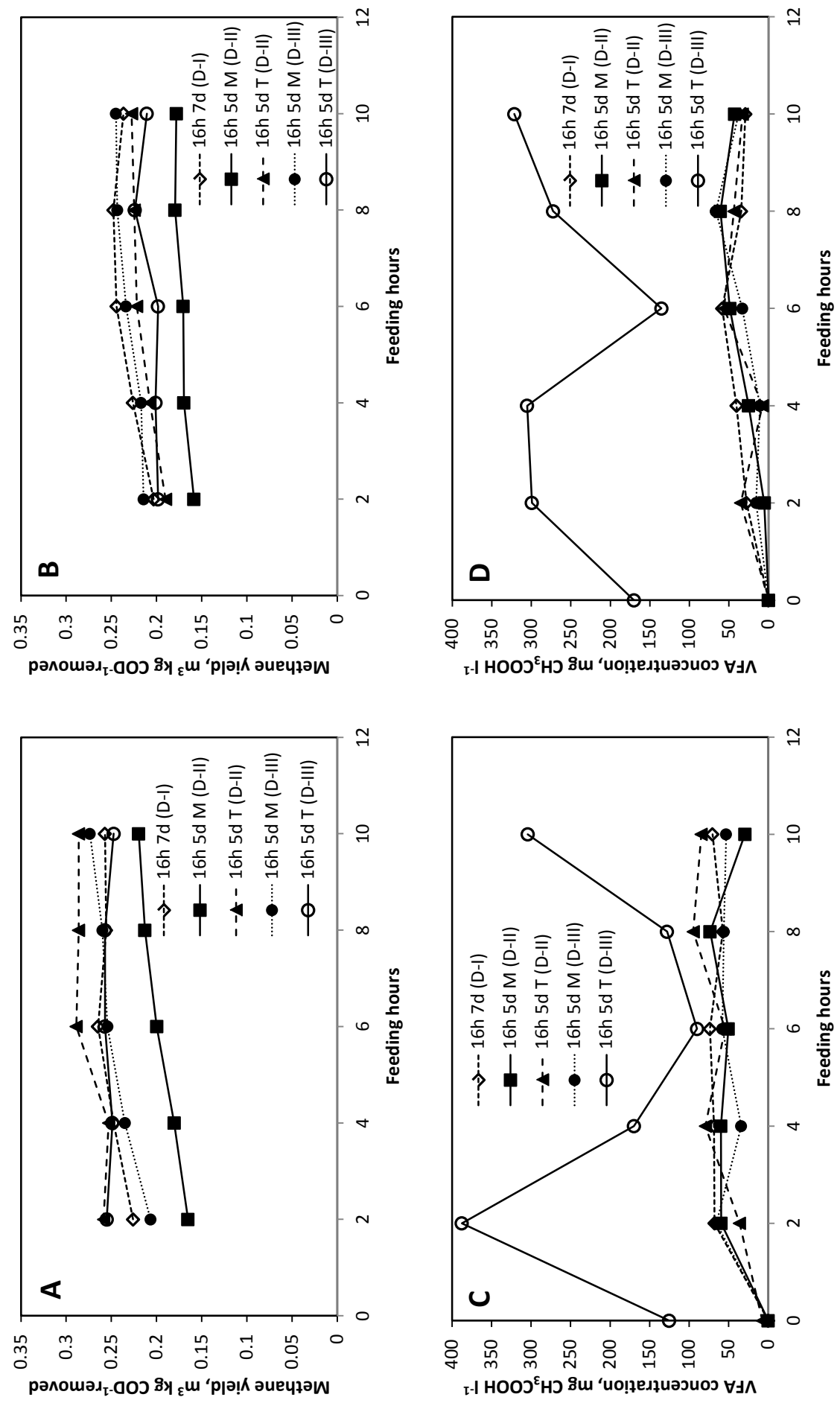

Fig 5 Hourly measurements of methane yield ( $\mathrm{m}^{3}$ methane $\mathrm{kg}^{-1} \mathrm{COD}_{\text {removed }}$ ) and VFA concentration (mg $\mathrm{CH}_{3} \mathrm{COOH} \mathrm{l}{ }^{-1}$ ) during operation under intermittent wastewater supply for R1, on the left, and R2, on the right. In the legend: label $16 \mathrm{~h} 7 \mathrm{~d}$ indicates a 
substrate supply of 16 hours per day, 7 days a week and 16 h 5 d indicates 16 hours per day, 5 days a week. M: denotes Monday; T: denotes Thursday 